\title{
ORGANIC ACIDS EFFECTS ON DESORPTION OF HEAVY METALS FROM A CONTAMINATED SOIL
}

\author{
Clístenes Williams Araújo do Nascimento \\ UFRPE - Depto. de Agronomia, R. Dom Manoel de Medeiros s/ $n^{\circ}$ - Dois Irmãos, 52171-900 - Recife, PE - \\ Brasil.e-mail <cwanascimento@yahoo.com>
}

\begin{abstract}
Phytoremediation of heavy metals is a biotechnology that extracts metals from soils and transfer them to plant. As hyperaccumulator species have demonstrated low potential for commercial phytoextraction, synthetic chelates have been successfully used to induce accumulation of metals by highbiomass plants. However, they pose serious environmental drawbacks regarding excessive amount of metals solubilized. In search for synthetic chelate-alternatives, this paper evaluate the performance of DTPA, EDTA, citric acid, oxalic acid, vanillic acid, and gallic acid in desorbing $\mathrm{Cd}, \mathrm{Pb}, \mathrm{Zn}, \mathrm{Cu}$, and $\mathrm{Ni}$ from soil. DTPA and EDTA were highly effective in desorbing $\mathrm{Cd}, \mathrm{Pb}, \mathrm{Zn}, \mathrm{Cu}$, and $\mathrm{Ni}$ from soil. However, the excessively high concentration of metals brought in solution by such chelates limits their application in the field. Citric and oxalic acids desorbed substantial quantities of $\mathrm{Zn}, \mathrm{Cu}$, and $\mathrm{Ni}$ if applied at 10 or 20 $\mathrm{mmol} \mathrm{kg}$. At the $20 \mathrm{mmol} \mathrm{kg}^{-1}$ dose, vanillic and gallic acids solubilized significant amounts of $\mathrm{Zn}, \mathrm{Ni}$, and $\mathrm{Cd}$ from soil. None of the tested low molecular weight organic acids substantially increased the $\mathrm{Pb}$ concentration in soil solution.
\end{abstract}

Key words: phytoremediation, phytoextraction, soil pollution

\section{ÁCIDOS ORGÂNICOS E SEUS EFEITOS NA DESSORÇÃO DE METAIS PESADOS EM SOLO CONTAMINADO}

\begin{abstract}
RESUMO: Fitoremediação de metais pesados é uma biotecnologia que usa plantas para extrair metais pesados de solos e transferi-los para a parte aérea. Como espécies naturalmente hiperacumuladoras de metais têm demonstrado baixo potencial para fitoextração comercial, agentes quelantes sintéticos são utilizados para induzir acumulação de metais em plantas de alta produção de biomassa. Esses quelantes, entretanto, apresentam a limitação ambiental de solubilizarem quantidades excessivamente altas de metais. Em busca de alternativas para o uso de quelantes sintéticos, o trabalho avaliou a capacidade de seis quelantes (DTPA, EDTA, ácido cítrico, ácido oxálico, ácido vanílico e ácido gálico) na dessorção de $\mathrm{Cd}, \mathrm{Pb}, \mathrm{Zn}, \mathrm{Cu}$ e Ni de um solo contaminado. DTPA e EDTA foram eficientes na dessorção de $\mathrm{Cd}, \mathrm{Pb}, \mathrm{Zn}, \mathrm{Cu}$ e Ni. No entanto, a alta solubilização de metais provocada por esses ácidos limita sua aplicação em condições de campo. Os ácidos cítrico e oxálico desorveram quantidades substanciais de $\mathrm{Zn}, \mathrm{Cu}$ e Ni quando aplicados nas doses de 10 e $20 \mathrm{mmol} \mathrm{kg}^{-1}$. Os ácidos vanílico e gálico na dose de $20 \mathrm{mmol} \mathrm{kg}^{-1}$ desorveram significantes quantidades de $\mathrm{Zn}$, Ni e Cd do solo. Nenhum dos ácidos naturais estudados foi eficiente na dessorção de $\mathrm{Pb}$ do solo.

Palavras-chave: fitoremediação, fitoextração, poluição de solo
\end{abstract}

\section{INTRODUCTION}

Phytoremediation has been developed as an economically and environmentally attractive approach to clean up heavy metal-polluted soils (Krämer, 2005; Pilon-Smits, 2005). One of the phytoremediation techniques, the so-called phytoextraction, relies on the use of plants to extract metals from soil and translocate them to shoots. The aim of phytoextraction is to reduce the concentration of metals in contaminated soils to regulatory levels within a reasonable time frame. Two approaches have currently been proposed to reach such goal: the use of plants with exceptionally high, natural metal-accumulating capacity, named hyperaccumulators, and the utilization of high-biomass crop plants, such as corn and Indian mustard in association with a chemically enhanced method of phytoextraction (Huang et al., 1997; Salt et al., 1998; Lombi et al., 2001; Chen et al., 2004).

The success of chemically-assisted phytoextraction was already demonstrated on field conditions for $\mathrm{Pb}$ enhanced-accumulation in Indian mustard driven by EDTA (Blaylock, 2000). However, the use of synthetic chelates has been strongly criticized because of the associated risk of groundwater contamination through metal leaching (Sun et al., 2001; Wenzel et al., 2003; Madrid et al., 2003; Meers et al., 2004; Chen et al., 2004). The use of easily biodegrad- 
able chelates has been thus proposed to enhance the metal soil availability and accumulation in plants while avoiding leaching risks (Nascimento et al., 2006).

This paper evaluates the ability of six chelate agents posing different chemical characteristics at solubilizing the heavy metals $\mathrm{Cd}, \mathrm{Pb}, \mathrm{Zn}, \mathrm{Cu}$, and $\mathrm{Ni}$ from an artificially contaminated soil. The potential of synthetic chelates and natural, aromatic or aliphatic low molecular weight organic acids (LMWOA) in providing metal concentrations in solution that are both environmentally safe and high enough to increase plant uptake up to levels adequate to phytoextraction is also discussed.

\section{MATERIAL AND METHODS}

Samples (0 to $20-\mathrm{cm}$ depth) of a Typic Fragiochrept (U.S. Soil Taxonomy) were air dried, passed through a $2 \mathrm{~mm}$ sieve, and analyzed for chemical and physical properties (Table 1). Samples of soil were amended with $\mathrm{CdCO}_{3}, \mathrm{C}_{2} \mathrm{H}_{2} \mathrm{O}_{8} \mathrm{~Pb}, \mathrm{ZnCO}_{3}$, $\mathrm{CuCO}_{3} \cdot \mathrm{Cu}(\mathrm{OH})_{2}$, and $\mathrm{NiCO}_{3}$ to achieve the concentrations of $50,500,300,200$, and $200 \mathrm{mg} \mathrm{kg}^{-1}$ of $\mathrm{Cd}, \mathrm{Pb}$, $\mathrm{Zn}, \mathrm{Cu}$, and $\mathrm{Ni}$, respectively. The carbonate salts were used to provide the metals in a limited solubility form, depending on their reaction with the soil (Blaylock et al., 1997). To reach equilibrium, the metal-amended samples were incubated for 40 -days at $80 \%$ of the water holding capacity.

Chelate agents posing different chemical characteristics: two synthetic chelates (EDTA ethylenediaminetetraacetic acid and DTPA diethylenediaminepentacetic acid), two natural aliphatic acids (oxalic and citric acids), and two natural aromatic acids (vanillic and gallic acids) were selected. To test the effects of chelates on heavy metals desorption from soil, 5 rates of each chelate $(0,2,5,10$, and $20 \mathrm{mmol} \mathrm{kg}$ ) were applied to contaminated soil samples $(3.0 \mathrm{~g})$, which were then suspended in $30 \mathrm{~mL}$ of $\mathrm{CaCl}_{2} 10 \mathrm{mmol} \mathrm{L}^{-1}$ and placed into a $50 \mathrm{~mL}$ disposable centrifuge tube.

Metal desorption was carried out by shacking the samples for $24 \mathrm{~h}$ at $300 \mathrm{rpm}$. The tubes were then centrifuged at $3000 \mathrm{x} g$ for $15 \mathrm{~min}$, the supernatant filtered, and the concentration of $\mathrm{Cd}, \mathrm{Pb}, \mathrm{Zn}, \mathrm{Cu}$, and $\mathrm{Ni}$ in the extracts analyzed by inductively coupled plasma optical emission spectrometry (ICP-OES) (Perkin Elmer optima 2000DV).

Data were reported as averaged values of three replicates. The best-fit regression equations between the chelate concentration applied to soil and the metal concentration in soil solution were chosen based on the highest $\mathrm{R}^{2}$ adjusted. Equations were then used to estimate the chelate concentration that caused highest metal solubilization and the highest amount of each metal brought into solution by each chelate. The statistical analysis was performed with SAEG software (Federal University of Viçosa, Brazil).

\section{RESULTS AND DISCUSSION}

EDTA and DTPA promoted higher concentrations of the heavy metals in solution than did LMWOA (Figure 1). This is clearly a function of the strength of the bond between a metal and a chelate agent, which is generally stronger for synthetic chelates compared to LMWOA (Martell \& Smith, 1974). Natural organic acids solubilized the highest amount of metals that are plant nutrients (i.e., $\mathrm{Zn}, \mathrm{Cu}$, and $\mathrm{Ni}$ ), whereas toxic metals $(\mathrm{Pb}$ and $\mathrm{Cd})$ were desorbed from soil in highest amounts by the synthetic chelates EDTA and DTPA.

Except for Ni-DTPA, which adjusted to a linear regression, the synthetic chelates at the tested concentrations range reached maximum desorption of metals from soil, with recovery rates varying from 41 to $100 \%$ (Table 2). On the other hand, only in the cases of $\mathrm{Cd}$ for oxalic acid and $\mathrm{Cd}$ and $\mathrm{Ni}$ for gallic acid, the concentration of natural LMWOA applied to soil was sufficient to reach a plateau. In such cases, equations are not presented in Table 2 . The recovery of $\mathrm{Cd}$ and $\mathrm{Ni}$ from soil by oxalic and gallic acid were much lower than the concentration recovered by synthetic chelates. This fact does not disqualify these acids for phytoextraction, since the solubilization of metals by DTPA and EDTA can be unnecessarily high.

DTPA and EDTA were noticeably effective in desorbing $\mathrm{Pb}$ whereas the natural organic acids solubilized very small amount of this metal from soil (Figure 1). Actually, the lower efficiency of LMWOA in making soil- $\mathrm{Pb}$ available to plants compared to synthetic chelates had already been demonstrated (Gupta

Table 1 - Selected chemical and physical properties of the soil used in the experiment.

\begin{tabular}{|c|c|c|c|c|c|c|c|c|c|c|c|c|c|c|}
\hline \multirow{2}{*}{$\mathrm{pH}$} & \multirow{2}{*}{$\mathrm{OM}$} & \multicolumn{3}{|c|}{ Texture } & \multicolumn{5}{|c|}{ DTPA } & \multicolumn{5}{|c|}{ Total (Aqua regia) } \\
\hline & & Clay & Silt & Sand & $\mathrm{Cd}$ & $\mathrm{Pb}$ & $\mathrm{Zn}$ & $\mathrm{Cu}$ & $\mathrm{Ni}$ & $\mathrm{Cd}$ & $\mathrm{Pb}$ & $\mathrm{Zn}$ & $\mathrm{Cu}$ & $\mathrm{Ni}$ \\
\hline & $-\cdots$ & $\cdots g$ & $s^{-1}-$ & ----- & $-\cdots$ & $\ldots$ & $\mathrm{g} \mathrm{kg}$ & $\ldots$ & $-\cdots$ & $\ldots$ & & $\mathrm{mg} \mathrm{k}$ & $\ldots$ & $-\cdots$ \\
\hline 4.5 & 21 & 150 & 490 & 360 & $<\mathrm{dl}$ & 0.5 & 0.1 & 0.3 & 0.1 & $<\mathrm{dl}$ & 12.1 & 85.3 & 17.4 & 16.3 \\
\hline
\end{tabular}

$\mathrm{dl}=$ metal concentration below the detection limit. 
et al., 2000; Lombi et al., 2001; Kos \& Lestan, 2004). LMWOA could not increase significantly the solubilization of $\mathrm{Pb}$ up to levels adequate for commercial phytoremediation, even at doses as high as $20 \mathrm{mmol}$ $\mathrm{kg}^{-1}$.

The major drawback for using synthetic chelates (especially EDTA) in field conditions is their high persistence to biodegradation, with consequent high risks of metal leaching through soil profile. The levels of heavy metals in soil solution after EDTA application can be much higher than plant's ability to absorb them (Madrid et al., 2003; Chen et al., 2004). Indeed, data of Table 2 show that EDTA and DTPA can solubilize up to 77 and $100 \%$ of $\mathrm{Pb}$ present in the soil samples, respectively. This was equivalent to bring 383 (EDTA) and $521 \mathrm{mg} \mathrm{kg}^{-1}$ (DTPA) of Pb into soil solution. Of course, such high values must be weighted against the use of these chelates for phytoextraction in the field.

The high capacity of DTPA to chelate Pb results from its higher stability constant with this metal $(\log \mathrm{K}=18.7)$ in comparison to Pb-EDTA $(\log \mathrm{K}=$ 17.9) (Martell \& Smith, 1974). However, only high metal solubilization from soil is not enough to guarantee efficient phytoextraction; the chelate must be also capable of increasing the transfer of metals from roots to shoots. For instance, Nascimento et al. (2006) reported higher concentration of $\mathrm{Pb}$ in soil solution in DTPA-treated soil than EDTA, but the root-to-shoot ratio of $\mathrm{Pb}$ in Indian mustard was $50 \%$ higher in EDTA-treated plants compared to plants treated with DTPA.

Citric and oxalic acids applied to soil at the $20 \mathrm{mmol} \mathrm{kg}{ }^{-1}$ dose desorbed substantial amounts of $\mathrm{Zn}$, $\mathrm{Cu}$, and $\mathrm{Ni}$ (Figure 1). The little impressive effects of these acids on metal solubilization (Krishnamurti et al., 1997; Renella et al., 2004; Kos \& Lestan, 2004) can result not only from their fast biodegradation but also from the relatively low doses tested in most works (5 to $\left.10 \mathrm{mmol} \mathrm{kg}^{-1}\right)$. Although doses higher than $10 \mathrm{mmol}$ $\mathrm{kg}^{-1}$ can be phytotoxic (Turgut et al., 2004), it is likely that to parcel the dose of citric or oxalic acids to avoid phytotoxicity could extend metals availability period for plant uptake. Actually, re-precipitation and/or readsorption on soil particles of metals released from easily biodegradable compounds are probably major reasons for the inefficiency of a single application of LMWOA in enhancing metal phytoextraction. This points to research needs to make the use of these environmentally-friendly phytoextraction enhancers feasible for commercial phytoextraction.

The aromatic LMOWA vanillic and gallic acids were the least effective in desorbing the metals from soil (Figure 1). This result is probably due to the low water solubility of such acids in comparison to the other chelates utilized. This fact leads to a lesser extent of reaction with metals bound to soil colloids or precipitated. The low ability of aromatic LMWOA to

Table 2 - Regression equations, dose for maximum desorption, estimated amount of metal in solution, and recovery rate for doses of chelates versus concentration of metals in a contaminated soil.

\begin{tabular}{|c|c|c|c|c|c|}
\hline Metal & Equation & $\mathrm{R}^{2}$ & Dose & Solubility & Recovery \\
\hline & & & $\mathrm{mmol} \mathrm{kg-1}$ & $\mathrm{mg} \mathrm{L}^{-1}$ & $\%$ \\
\hline & \multicolumn{5}{|c|}{ EDTA } \\
\hline $\mathrm{Cd}$ & $Y=-0.08 x^{3}+2.60 x^{2}-20.91 x-3.39$ & $0.92 * *$ & 20.2 & 28.1 & 57 \\
\hline $\mathrm{Pb}$ & $Y=-0.36 x^{3}+9.35 x^{2}-28.89 x+10.19$ & $0.99 * *$ & 18.9 & 383.3 & 77 \\
\hline $\mathrm{Zn}$ & $Y=-0.80 x^{2}+28.85 x+9.48$ & $0.94 * *$ & 18.0 & 269.6 & 90 \\
\hline $\mathrm{Cu}$ & $Y=-0.64 x^{2}+19.53 x+14.64$ & $0.94 * *$ & 15.6 & 163.6 & 54 \\
\hline \multirow[t]{2}{*}{$\mathrm{Ni}$} & $Y=-0.17 x^{2}+7.05 x+8.56$ & $0.94 * *$ & 20.7 & 81.7 & 41 \\
\hline & \multicolumn{5}{|c|}{ DTPA } \\
\hline $\mathrm{Cd}$ & $Y=-0.21 x^{2}+5.51 x+2.48$ & $0.96 * *$ & 13.4 & 38.6 & 77 \\
\hline $\mathrm{Pb}$ & $Y=-2.24 x^{2}+66.37 x+29.38$ & $0.97 * *$ & 14.8 & 521.0 & 104 \\
\hline $\mathrm{Zn}$ & $Y=-0.92 x^{2}+31.17 x+5.21$ & $0.99 * *$ & 17.3 & 245.2 & 82 \\
\hline \multirow[t]{2}{*}{$\mathrm{Cu}$} & $Y=-0.56 x^{2}+19.23 x+2.70$ & $0.99 * *$ & 17.2 & 167.8 & 84 \\
\hline & \multicolumn{5}{|c|}{ Oxalic acid } \\
\hline \multirow[t]{2}{*}{$\mathrm{Cd}$} & $Y=-0.06 x^{2}+1.88 x+2.22$ & $0.81 * *$ & 15.7 & 16.9 & 34 \\
\hline & \multicolumn{5}{|c|}{ Gallic acid } \\
\hline $\mathrm{Cd}$ & $Y=-0.04 x^{2}+1.31 x+1.33$ & $0.90 * *$ & 15.3 & 12.0 & 2 \\
\hline $\mathrm{Ni}$ & $Y=-0.04 x^{2}+1.48 x+1.31$ & $0.96 * *$ & 21.3 & 14.7 & 7 \\
\hline
\end{tabular}

**Significant at $1 \%$. 

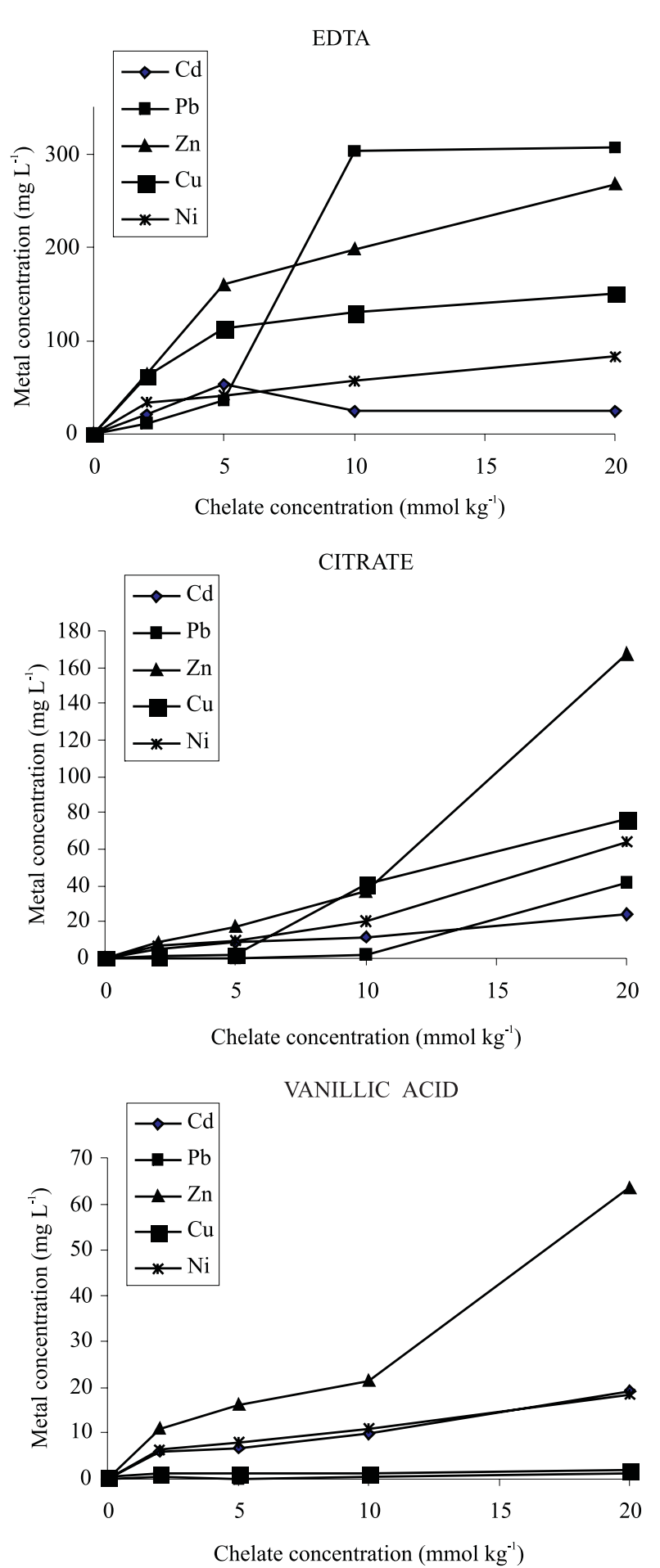

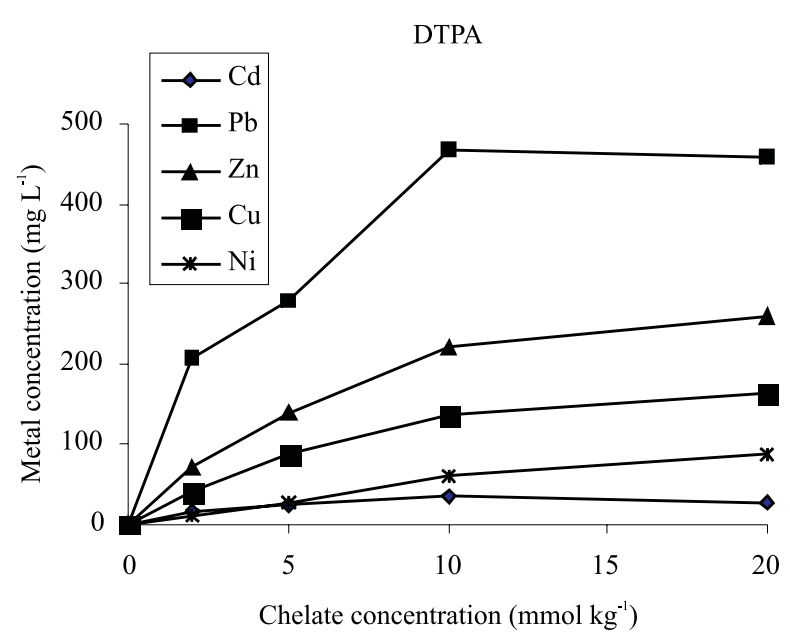

OXALATE
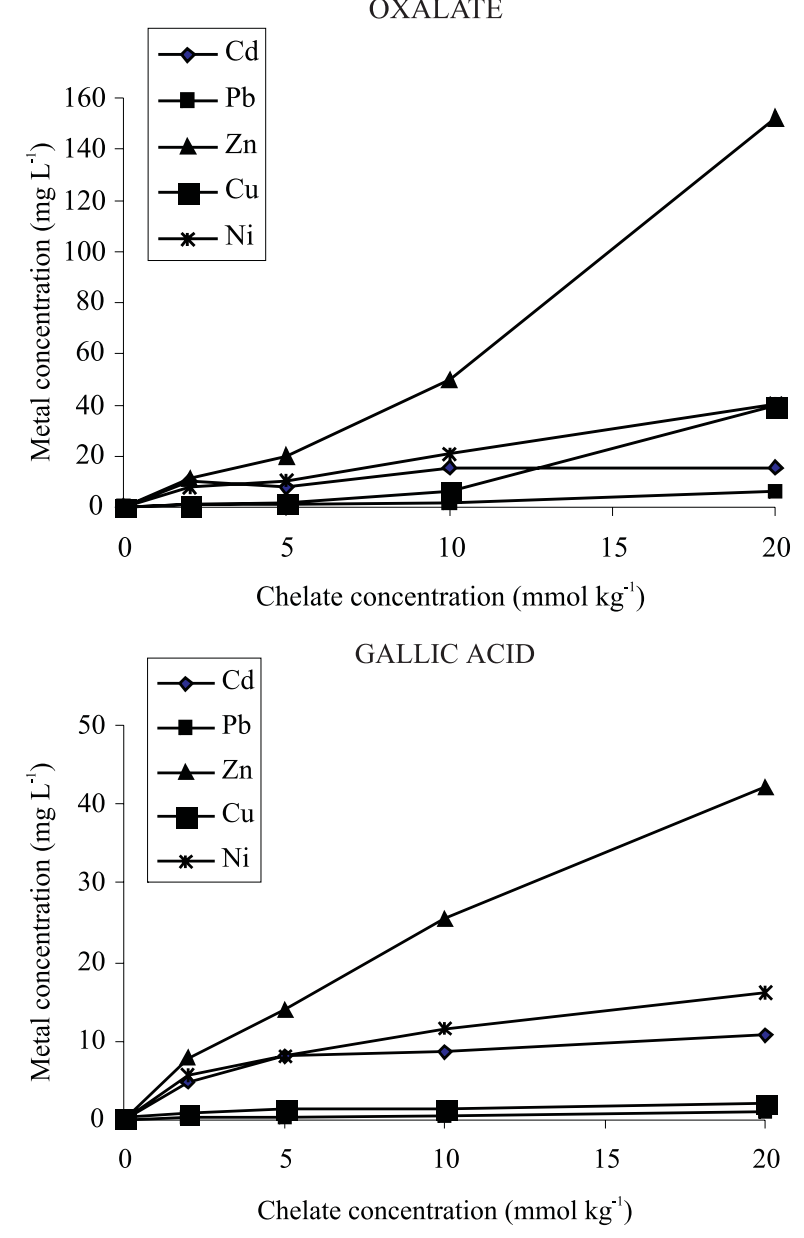

Figure 1 - Effect of chelates applied at different concentrations on desorbing $\mathrm{Cd}, \mathrm{Pb}, \mathrm{Zn}, \mathrm{Cu}$, and $\mathrm{Ni}$ from soil. Values are means of three replicates.

complex $\mathrm{Pb}$ and $\mathrm{Cu}$, the least soluble among the studied metals, corroborates such an assumption. However, high doses (i.e. 10 and $20 \mathrm{mmol} \mathrm{kg}^{-1}$ ) of vanillic and gallic acids increased substantially the concentration of $\mathrm{Zn}$ in the soil solution (Figure 1). Nascimento et al. (2006) demonstrated that gallic acid applied at 10 mmol $\mathrm{kg}^{-1}$ could remove as much $\mathrm{Cd}, \mathrm{Zn}, \mathrm{Cu}$, and $\mathrm{Ni}$ from soil as EDTA without increasing the leaching risk. Therefore, as highlighted to aliphatic LMWOA, more studies on doses and application timing of natural aromatic LMWOA are needed to make the use of these compounds in phytoextraction a viable alternative to synthetic chelates application. In addition, the use of natural compounds in contraposition to synthetic che- 
lates sounds better for the public acceptance of phytoextraction as a technology to clean up metal-polluted soils.

\section{REFERENCES}

BLAYLOCK, M.J. Field demonstrations of phytoremediation of leadcontaminated soils. In: TERRY, N., BAÑUELOS, G. (Ed.). Phytoremediation of contaminated soil and water. Boca Raton: Lewis Publisher, 2000. p.1-12.

BLAYLOCK, M.J.; SALT, D.E.; DUSHENKOV, S.; ZHAKAROVA, O.; GUSSMAN, C.; KAPULNIK, Y.; ENSLEY, B.D.; RASKIN, I. Enhanced accumulation of $\mathrm{Pb}$ in Indian mustard by soil-applied chelating agents. Environmental Science and Technology, v.31, p.860-865, 1997.

CHEN, Y.; XIANGDONG, L.; SHEN, Z. Leaching and uptake of heavy metals by ten different species of plants during an EDTA-assisted phytoextraction process. Chemosphere, v.57, p.187-196, 2004.

GUPTA, S.K.; HERREN, T.; WENGER, K.; KREBS, R.; HARI, T. In situ gentle remediation measures for heavy metal-polluted soils. In: TERRY, N.; BAÑUElos, G. (Ed.). Phytoremediation of contaminated soil and water. Boca Raton: Lewis Publisher, 2000. p.303-322.

HUANG, J.W.; CHEN, J.J.; BERTI, W.R.; CUNNINGHAM, S.D. Phytoremediation of lead-contaminated soils: role of synthetic chelates in lead phytoextraction. Environmental Science and Technology, v.31, p.800-805, 1997.

KOS, B.; LESTAN, D. Chelator induced phytoextraction and in situ soil washing of $\mathrm{Cu}$. Environmental Pollution, v.132, p.333-339, 2004.

KRÄMER, U. Phytoremediation: novel approaches to cleaning up polluted soils. Current Opinion in Biotechnology, v.2, p.133-141, 2005.

KRISHNAMURTI, G.S.R.; CIESLINSKI, G.; HUANG, P.M.; VAN PEES, K.C.J. Kinectics of cadmium release from soils as influenced by organic acids: implication in cadmium availability. Journal of Environmental Quality, v.26, p.271-277, 1997.

LOMBI, E.; ZHAO, F.J.; DUNHAM, S.J.; MCGRATH, S.P. Phytoremediation of heavy-metal contaminated soils: natural hyperaccumulation versus chemically enhanced phytoextraction. Journal of Environmental Quality, v.30, p.1919-1926, 2001.
MADRID, F.; LIPHADZI, M.S.; KIRKHAM, M.B. Heavy metal displacement in chelate-irrigated soil during phytoremediation. Journal of Hydrology, v.271, p.107-119, 2003.

MARTELL, W.E.; SMITH, W.M. Critical stability constants. Amino acids. New York: Plenum Press, 1974. v.1.

MEERS, E.; HOPGOOD, M.; LESAGE, E.; TACK, F.M.G.; VERLOO, M.G. Enhanced phytoextraction: in search for EDTA alternatives. International Journal of Phytoremediation, v.6, p.95-109, 2004.

NASCIMENTO, C.W.A.; AMARASIRIWARDENA, D.; XING, B. Comparison of natural organic acids and synthetic chelates at enhancing phytoextraction of metals from a multi-metal contaminated soil. Environmental Pollution, v. 140, p.114-123, 2006.

PILON-SMITS, E. Phytoremediation. Annual Review of Plant Biology, v.56, p.15-39, 2005.

RENELLA, G.; LANDI, L.L.; NANNIPIERI, P. Degradation of low molecular weight organic acids complexed with heavy metals in soil. Geoderma, v.122, p.311-315, 2004.

RÖMKENS, P.; BOUWMAN, L.; JAPENGA, J.; DRAAISMA, C. Potentials and drawbacks of chelate-enhanced phytoremediation of soils. Environmental Pollution, v.116, p.109-121, 2002.

SALT, D.E.; SMITH, R.D.; RASKIN, I. Phytoremediation. Annual Review Plant Physiology Plant Molecular Biology, v.49, p.643668,1998

SUN, B.; ZHAO, F.J.; LOMBI, E.; MCGRATH, S.P. Leaching of heavy metals from contaminated soils using EDTA. Environmental Pollution, v.113, p.111-120, 2001.

TURGUT, C.; PEPE, M.K.; CUTRIGHT, T.J. The effect of EDTA and citric acid on phytoremediation of $\mathrm{Cd}, \mathrm{Cr}$, and $\mathrm{Ni}$ from soil using Helianthus annuus. Environmental Pollution, v.131, p.147-154, 2004.

WENZEL, W.W.; UNTERBRUNNER, R.; SOMMER, P.; SACCO, P. Chelate-assisted phytoextraction using canola (Brassica napus L.) in outdoors pot and lysimeter experiments. Plant and Soil, v.249, p.83-96, 2003

Received June 27, 2005

Accepted May 19, 2006 